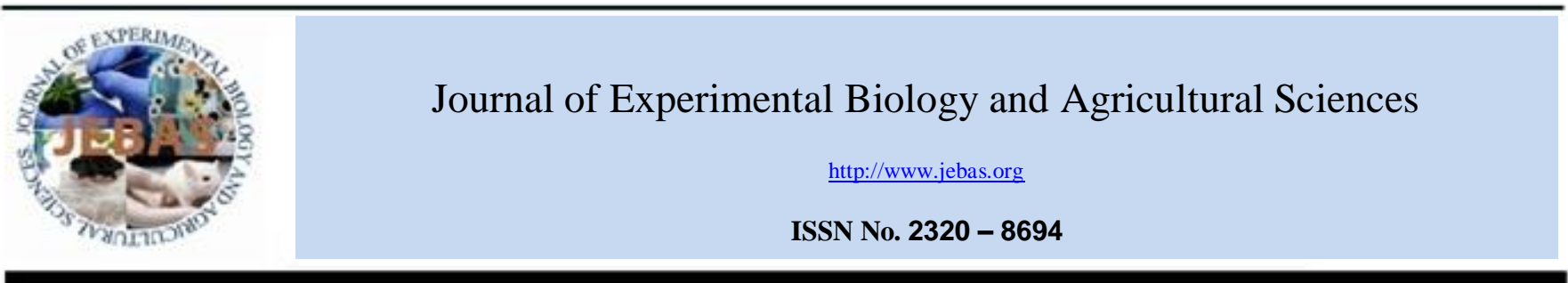

\title{
EXPERIENCE OF DIAGNOSTICS AND CONTAINMENT OF FOOT AND MOUTH DISEASE OF CATTLE IN KRASNODAR REGION, RUSSIA
}

\section{Oleg Urievich Chernykh*, Andrey Georgievich Koshchaev, Alexander Anatolyevich Lysenko, Alexander Alekseevich Shevchenko, Aleksey Vladimirovich Mishchenko}

Kuban State Agrarian University, Krasnodar, Kalinina Street, 13, Russia, 350044

Received - July 02, 2017; Revision - October 16, 2017; Accepted - December 02, 2017

Available Online - December 27, 2017

DOI: http://dx.doi.org/10.18006/2017.5(6).786.792

KEYWORDS
Foot-and-mouth disease
Krasnodar region
Type A virus
Vaccination
Prevention
Rehabilitation
Immunity
Antibodies

* Corresponding author

E-mail: kagbio@mail.ru (Oleg Urievich Chernykh)

Peer review under responsibility of Journal of Experimental Biology and Agricultural Sciences.

Production and Hosting by Horizon Publisher India [HPI] (http://www.horizonpublisherindia.in/).

All rights reserved.

\begin{abstract}
A retrospective analysis of the epizootic situation with foot-and-mouth disease in Krasnodar region has been provided in 2013. Results of study indentified, type A, Asia topotype, Iran 05 genetic lines, SIS-10 sub-linage has been identified for foot-and-mouth disease. Laboratory tests proved that over $75 \%$ of animals were immune in the blood collected after 60-80 days vaccination. Field efficiency of foot-andmouth disease vaccines does not always correspond to the characteristics obtained during the quality control of the vaccine manufacturer. If master seed strain matches epizootic isolates, mass vaccination creates herd immunity, prevents an outbreak, and stabilizes the epizootic process that has begun. Taking into consideration the threat of penetration of the virus into the territory of Russia, regular vaccination of ruminant animals and control of the level of vaccine-induced antibodies are required in the buffer zone.
\end{abstract}

All the article published by Journal of Experimental Biology and Agricultural Sciences is licensed under a Creative Commons Attribution-NonCommercial 4.0 International License Based on a work at www.jebas.org.

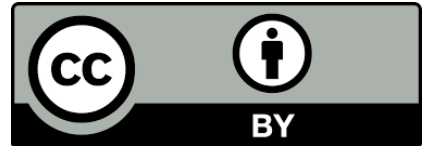




\section{Introduction}

Recently, the epizootic situation with some transboundary infectious diseases (foot-and-mouth disease, lumpy skin disease, pest of small ruminants) has become much more complicated throughout the world. Foot and mouth disease is one of the highly contagious diseases of cloven-hoofed animals. The epizootic situation with foot and mouth disease in the countries next to the Russian Federation remains tense, which presents constant threat of penetration of the virus into the territory of Russia. Analysis of data on outbreaks of foot-and-mouth disease in various countries viz., UK, Japan, France, the Netherlands, Taiwan indicates that this virus can penetrate into any country at any time (Mischenko, 2015).

The virus of foot-and-mouth disease type A, Asia topotype, Iran 05 genetic line was first discovered in 2003 from Iran. This pathogen spread widely throughout the Middle East in 2005-2006, including in Iran, Iraq, Turkey, Pakistan and Afghanistan. Later, the virus diverged significantly, and number of sub-linages appeared within the genetic line. The causative agent that belongs to the SIS 10 sub-linage of the foot and mouth disease virus Iran 2005 has dominated in Turkey since 2011, and in Iran since 2012 (Mischenko, 2015; Kharatyan, 2016; Plutakhin et al., 2016; Onischuk et al., 2016).

The outbreaks of foot-and-mouth disease in cattle caused by the virus of type A belonging to the G-VII genetic line Asia topotype were recorded on the territory of Saudi Arabia, Turkey, Iraq, and Iran in September-November 2015 (Mischenko, 2015). This pathogen related to the virus recovered in 2002-2004 from samples of pathological material from cattle infected with footand-mouth disease from India. Foot-and-mouth disease in cattle and swine was also recorded at the farm of the Arazan community of Armavir marz in Armenia in December 23, 2015. The Arazan community is situated on the state border with Turkey in the south. The laboratory tests discovered the foot-and-mouth disease virus of type A, G-VII genetic line Asia topotype in the samples of pathological material. According to the veterinary experts of Armenia, the probable cause of the foot-and-mouth disease virus were sick animals on the pastures of Turkey bordering the Arazan. It was assumed that the causative agent penetrated with air currents or wild animals (Kharatyan, 2016).

Exacerbation of the epizootic situation of foot and mouth disease is often explained by the emergence of new strains of the pathogen, high contagiousness of the disease, multiple pathways and mechanisms of the virus transmission (Shcherbakov et al., 2013; Knight-Jones et al., 2014; Upadhyaya et al., 2014; Mishchenko \& Mishchenko, 2015). International practice of prevention and elimination of foot-and-mouth disease assumes prevention of penetration of a pathogen into an unharmed country.
The system of measures to control foot-and-mouth disease is limited to veterinary, sanitary and quarantine restrictive measures, including destruction (stamping out or modified stamping out) of sick animals and all animals suspected of being infected and sick, quarantine and involuntary ring vaccination (Burdov et al., 1990; Starostina et al., 1997; Mishchenko et al., 2013; Radchenko et al., 2016).

Practice of eliminating the outbreaks of foot-and-mouth disease indicates that the timely epizootic and clinical diagnostics plays a primary role in the system of measures for stabilizing and eliminating the disease. The control measures for stabilizing footand-mouth disease in the primary site are the most efficient (Mishchenko et al., 2011).

\section{Materials and Methods:}

In present study, identification and diagnosis of the disease and pathogen was carried out by standard methodology prescribed for foot and mouth disease. During the study, epizootic situation of adjacent territories was also analyzed and the practices related to the livestock management, clinical signs, productivity and results of thermometry were considered on priority. In order to conduct laboratory tests for cattle foot-and-mouth disease the walls and contents of aphthas on the mucous membrane of the tongue, the coronet skin and the interdigital slit were collected. Further unopened aphtha were collected the from animals with clinical signs that give grounds for suspecting the foot-and-mouth disease, namely oppression, abundant salivation, a decrease in milk productivity, fever. Virological studies were conducted in the Federal Centre for Animal Health (FGBI “ARRIAH”), resulting in the discovery of the genotype of the foot-and-mouth disease virus type A isolate A2166/Krasnodar/2013 of the genetic line "Iran-2005", "Asia" topotype, which was genetically similar to the isolates A2167/Pregradnoe/Karachaevo-Cherkess/2013 and A2164/Gamruha/Karachaevo-Cherkess/2013. The level of post vaccinal antibodies was determined by ELISA. The reaction was set up using the "Foot-and-mouth antibodies in the blood serum of animals ELISA detection kit" in accordance with its manual.

The prophylactic efficacy of vaccines was evaluated in large groups of cattle under conditions of farms in the framework of antiepizootic measures. Determination of protective antibodies level after vaccination was determined in accordance with the "Manual for the use of the Foot-and-mouth antibodies in the blood serum of animals ELISA detection kit" approved on 09.07.2013 by the FGBI "ARRIAH". The quality of vaccination was considered satisfactory, if not less than $80 \%$ of the animals showed antibodies to the vaccine strain.

Cases of vesicular lesions in young cattle that belonged to residents of the Karachaevo-Cherkess Republic were recorded in 
late May 2013. Ruminant animals were vaccinated against footand-mouth disease in October 2012. Clinical examination of animals revealed various clinical signs such as distress, loss of appetite, reduction or cessation of lactation, salivation. A causative agent of pasteurellosis was detected in the selected samples of pathological material in the Karachaevo-Cherkess Republic Veterinary Laboratory. A mass disease of cattle was recorded in Predgornoye village in late May and early June 2013. During clinical examination, vesicular lesions were detected in animals. Foot-and-mouth disease virus of type A, Asia topotype, Iran 05 genetic line, SIS-10 sub-linage was detected during the study of samples of pathological material on June 10, 2013 in Federal Centre for Animal Health (FGBI "ARRIAH"). Further, cases of foot-and-mouth disease in cattle were revealed in 3 more settlements in the District Urupsky and the incidence rate was within 10.0-17.9\% (average 15.0\%). Postvaccinal immunity and level of colostral immunity in young cattle were studied by using standard serological method prescribed in literature.

\section{Results and Discussion}

Results of study define the antigenic commonality carried out at the FGBI "ARRIAH" revealed that used vaccines viz., A22 IRQ, A Iran 2005, A TUR 20/06, A/Asia/SEA-97 and A/Iran/05/SIS 10 , did not provide protection to the animals from foot-and-mouth disease virus of type A, G-VII genetic line (Rakhmanov et al., 2013). The outbreaks of foot-and-mouth disease were recorded in 2013 on the territory of the Zabaykalsky region and the Amur region, which are part of the buffer foot-and-mouth zone. The recovered isolates of the foot-and-mouth disease virus of type A belonged to the South-East Asia-97 genetic line (SEA-97). The causative agent of this genetic line was discovered on the territory of the Russian Federation for the first time and it was reported that this foot-and-mouth disease virus came from China. The recovered causative agent was identical (genetic commonality is 99.65\%) to the virus isolates circulating in China. The results of epizootic examinations of the foot-and-mouth disease outbreaks led to conclusion about the low field efficacy of the foot-andmouth vaccines used in the buffer zone in 2013 (Dzhailidi et al., 2013).

The Krasnodar region has been unharmed by foot-and-mouth disease since 1980, this region veterinary specialist carried out timely active immunization of animals with the foot-and-mouth cultural mono- and polyvalent fiber-entrapped inactivated vaccine of types A, O, Asia-1 (Dzhailidi et al., 2013; Parilet al., 2014).

Despite this, hotbeds of foot-and-mouth disease were recorded in the Mostovskoy district in 2013. The causes for foot-and-mouth disease penetration into the territory of the Krasnodar region included untimely provision of information by the State Veterinary Service of Kuban about the disease in animals on the territory of the Karachaevo-Cherkess Republic and the unmatched antigenic composition of the vaccine and field strains of the virus. The FGBI "ARRIAH" recovered the genotype of the foot-andmouth disease virus type A isolate A2166/Krasnodar/2013 of the genetic line "Iran-2005", "Asia" topotype, which was genetically similar to the isolates A2167/Pregradnoe/KarachaevoCherkess/2013 and A2164/Gamruha/ Karachaevo-Cherkess/2013 (Dzhailidi et al., 2013).

The Krasnodar region borders the Rostov region in the north and the Stavropol region in the east, the Karachaevo-Cherkess Republic and the Republic of Abkhazia in the southeast. As of July 1, 2013, there were 543,760 cattle and 128,839 small cattle in the Krasnodar region. This highlights the danger of foot-andmouth disease spreading to the border regions, which could lead to significant economic losses. The situation could have developed under the scenario of 1976, when foot-and-mouth disease covered most of the Krasnodar region (Table 1).

Table 1 Foot-and-mouth disease recorded on the territory of the Krasnodar region in 1976 and 2013

\begin{tabular}{|l|l|}
\hline \multicolumn{2}{|c|}{1976} \\
\multicolumn{2}{|c|}{ Foot-and-mouth disease was recorded in: } \\
\hline $\begin{array}{l}26 \text { districts } \\
79 \text { collective farms } \\
30 \text { state farms } \\
7 \text { interdistrict feeding sites }\end{array}$ & $\begin{array}{l}1 \text { district } \\
3 \text { settlements } \\
21 \text { farmsteads of the population }\end{array}$ \\
\hline \multicolumn{2}{|c|}{ Sick animals by species: } \\
\hline $\begin{array}{l}\text { 13,500 cattle } \\
670 \text { small cattle } \\
354,000 \text { swine }\end{array}$ & 48 cattle \\
\hline
\end{tabular}

The State Veterinary Administration of the Krasnodar region received information from the State Veterinary Administration of the Mostovskoy district about the suspected foot-and-mouth disease in animals at private farms in Solenoye village. After onsite inspection of the place of the alleged outbreak and examination of animals, it was established that 8 animals had clinical signs of foot-and-mouth disease. The pathological material was immediately taken and sent to the FGBI "ARRIAH". In May-June 2013, foot-and-mouth disease in vaccinated cattle in the Karachaevo-Cherkess Republic, the Krasnodar region and the Kabardino-Balkar Republic was recorded. The A2166/Krasnodar/2013 isolate of "Iran-2005" genetic line, "Asia" topotype was recovered from samples of pathological material from sick animals, which was exotic for the Russian Federation and genetically similar to isolates A2167/Pregradnoe/KarachaevoCherkess/2013 and A2164/Gamruha/Karachaevo-Cherkess/2013 (Shcherbakov et al., 2014). These foot-and-mouth disease virus 
had been isolated in 12 hotbeds of infection located in the Mostovskoy district from June 29, 2013 to July 1, 2013.

The Mostovskoy district is located in the foothills of the Caucasus Mountains and borders the Republic of Adygea in the north and northeast and the Karachaevo-Cherkess Republic in the south. There were 11,758 cattle and 2,940 small cattle in the Mostovskoy district on July 1, 2013. Ruminant animals in the Mostovskoy district were immunized with trivalent foot-and-mouth vaccine A, O, Asia-1 in April 2013 and revaccinated in June 2013. Characteristics of epizootic hotbeds of foot-and-mouth disease in Mostovskoy district are presented in Table 2.

Table 2 Characteristics of hotbeds of foot-and-mouth disease of type A in the Mostovskoy district in 2013

\begin{tabular}{|c|cc|ccccc|}
\hline Date & Hotbeds & Cattle & $\begin{array}{l}\text { Small } \\
\text { cattle }\end{array}$ & $\begin{array}{l}\text { Quantity } \\
\text { Cattle infected } \\
\text { with foot-and- } \\
\text { mouth disease }\end{array}$ & $\begin{array}{c}\text { Small } \\
\text { cattle }\end{array}$ \\
\hline 15.06 .13 & Solenoye & 161 & 101 & 8 & 5.0 & 0 \\
\hline 26.06 .13 & Andryuki & 180 & 101 & 4 & 2.2 & 0 \\
\hline 26.06 .13 & Psebai & 54 & 147 & 6 & 11.1 & 0 \\
\hline & Total & 395 & 346 & 18 & 4.6 & 0 \\
\hline
\end{tabular}

Data presented in table revealed that 18 heads (4.6\%) out of 395 cattle fell sick in three communities located in close proximity to each other.

Table 3 shows the data of laboratory tests of 1,015 samples of blood serum of cattle from 92 farms of 7 districts of the Krasnodar region, carried out in FGBI "ARRIAH" and the State "Kropotkin Regional Veterinary Laboratory" in the Krasnodar region, which indicated the heterogeneity of the level of foot-and-mouth antibodies. The prevalence of antibodies to the foot-and-mouth disease virus was $66 \%(39-100 \%)$ on average for type A, 78\% (39-100\%) for type O, $84 \%$ (54-100\%) for type Asia-1. At the same time, the data of laboratory tests of 196 samples of blood serum of cattle collected 4 to 25 days after vaccination from 19 farms in the Mostovskoy district for the presence of postvaccination foot-and-mouth antibodies suggested a low level of their prevalence. Antibodies to the foot-and-mouth disease virus of type A were detected in $43 \%$ of the samples, to the virus of the type $\mathrm{O}$ in $67 \%$ of the samples, and to the virus of type Asia-1 - in $80 \%$ of the samples. The obtained data indicated that $57 \%$ cattle was not immune to foot-and-mouth disease of type A, and 33\% cattle were not immune to the virus of type $\mathrm{O}$. The low prevalence of antibodies to the foot-and-mouth disease virus of type A was common for the most part of tested blood sera. Conclusions about the low field efficiency of the foot-and-mouth vaccines used in the Krasnodar region in 2013 were based on data obtained from the study (Mikhalishin, 2013; Dzhailidi et al., 2013; Paril et al., 2014, Koshchaev et al.,2016).

Table 3 Results of surveillance studies of blood serum of cattle vaccinated against foot-and-mouth disease for the presence of postvaccinal foot-and-mouth antibodies

\begin{tabular}{|c|c|c|c|c|c|}
\hline \multirow[t]{2}{*}{ District } & \multicolumn{2}{|c|}{ Quantity } & \multicolumn{3}{|c|}{$\begin{array}{l}\text { Percentage sera containing } \\
\text { antibodies against foot-and- } \\
\text { mouth disease virus }\end{array}$} \\
\hline & Farms & Samples & A & $\mathrm{O}$ & Asia-1 \\
\hline Otradnensky & 28 & 166 & 67 & 77 & 84 \\
\hline Labinsky & 27 & 293 & 68 & 82 & 82 \\
\hline Mostovskoy & 19 & 196 & 43 & 67 & 80 \\
\hline Kuschevsky & 1 & 28 & 67 & 96 & 100 \\
\hline Novokubansky & 8 & 123 & 78 & 86 & 86 \\
\hline Gulkevichsky & 1 & 70 & 100 & 100 & 100 \\
\hline Caucasian & 8 & 80 & 39 & 39 & 54 \\
\hline Total & 92 & 1015 & $\begin{array}{c}66 \\
(39-100)\end{array}$ & $\begin{array}{c}78 \\
(39-100)\end{array}$ & $\begin{array}{c}84 \\
(54-100)\end{array}$ \\
\hline
\end{tabular}

The data provided in Table 3 allowed to conclude that the field efficiency of foot-and-mouth vaccines depends on multiple factors and will not always correspond to the characteristics obtained during the quality control of the vaccine manufacturer.

If master seed strain matches epizootic isolates, mass vaccination allows to create herd immunity, prevent an outbreak and stabilize the epizootic process that has begun (Mikhalishin, 2013, Rakhmanov et al., 2013; Mishchenko et al., 2013). According to Knight-Jones et al. (2015) individual resistance of cattle is described by the formation of cellular and humoral immunity with the relevant immune response.

Immunological efficiency of antiviral vaccines was evaluated by their protectiveness and antigenicity. Dairy cows in those adverse locations were vaccinated against foot-and-mouth disease at 5-6 months of pregnancy. Table 3 shows the results of tests of blood sera of newborn calves (up to 30 days old) for the presence of foot-and-mouth postvaccinal colostral antibodies.

The data provided in Table 4 indicated different levels of the footand-mouth colostral antibodies were found in the sera of newborn calves. Antibodies to the foot-and-mouth disease virus of type A were found in $50 \%$ of samples, antibodies to the virus of type $\mathrm{O}$ and Asia-1 were found in $47 \%$ of sera. The foot-and-mouth antibodies were detected only in very low titers and in individual newborn calves (up to 30 days of age) born 120-130 days after vaccination of cows against foot-and-mouth disease (Nersesyan et al., 1997). 
Table 4 Results of tests of blood sera of newborn calves (2-30 days of age) born from cows vaccinated against foot-and-mouth disease for the presence of colostral antibodies

\begin{tabular}{|l|ccccc|}
\hline $\begin{array}{c}\text { Calves } \\
\text { age } \\
\text { (days) }\end{array}$ & $\begin{array}{c}\text { Time of } \\
\text { calving } \\
\text { after } \\
\text { vaccination } \\
\text { of cows } \\
\text { (days) }\end{array}$ & $\begin{array}{c}\text { Number } \\
\text { of } \\
\text { samples }\end{array}$ & \multicolumn{3}{c|}{$\begin{array}{c}\text { Percentage samples } \\
\text { containing antibodies } \\
\text { against foot-and-mouth } \\
\text { disease virus }\end{array}$} \\
\hline 4-12 & $30-45$ & 25 & 56 & 76 & A \\
\hline 2-8 & $35-51$ & 25 & 72 & 96 & 96 \\
\hline up to 30 & $42-51$ & 13 & 100 & 83 & 100 \\
\hline up to 30 & $45-52$ & 10 & 100 & 70 & 70 \\
\hline 6-9 & $49-52$ & 10 & 60 & 60 & 60 \\
\hline 4-10 & $51-60$ & 10 & 80 & 70 & 70 \\
\hline $3-8$ & $54-60$ & 10 & 90 & 90 & 90 \\
\hline up to 30 & $65-75$ & 30 & 43 & 30 & 33 \\
\hline up to 30 & $120-130$ & 10 & 20 & 0 & 20 \\
\hline up to 30 & $135-139$ & 10 & 30 & 20 & 0 \\
\hline up to 30 & $143-150$ & 10 & 20 & 0 & 0 \\
\hline up to 30 & $152-163$ & 10 & 0 & 0 & 10 \\
\hline up to 30 & $166-175$ & 10 & 0 & 0 & 0 \\
\hline Average & 183 & 50 & 47 & 47 \\
\hline
\end{tabular}

Various measures were taken by the State Veterinary Service of the region in order to prevent the emergence of new hotbeds of foot-and-mouth disease on the territory of Kuban and to exclude the possibility of its spread across the territory of the Russian Federation:

1. Resolution of the Head of Administration (Governor) of the Krasnodar region dated June 7, 2013 No. 597 "Concerning the strengthening of measures to prevent penetration of the virus and foot-and-mouth disease in animals on the territory of the Krasnodar region" was adopted;

2. Order of the Head of State Veterinary Administration of the Krasnodar region dated June 10, 2013, No. 108 "Concerning the definition of a threatened area for foot-and-mouth disease in animals on the territory of the Krasnodar region" was issued, where threatened areas were defined as the Mostovskoy, Labinsky and Otradnensky districts of the region;

3. Resolution of the Head of Administration (Governor) of the Krasnodar region dated July 1, 2013 No. 671 "Concerning the establishment of restrictive measures (quarantine) on the territory of the Mostovskoy district of the Krasnodar region" was adopted, and the Decision of the Commission for Prevention and Control of Emergencies and Fire Safety of the Municipal Administration of the Mostovskoy district dated July 2, 2013 No.12 introduced the "Emergency" mode on the entire territory of the Mostovskoy district municipality on July 2, 2013;

4. According to the Resolution of the Head of Administration (Governor) of the Krasnodar region dated July 16, 2013, No. 635-r, the "High Alert" mode was introduced throughout the entire territory of the region on July 4, 2013 for the management bodies and forces of the territorial subsystem of the unified state system of prevention and control of emergencies involved in the events aimed at preventing the spread of foot-and-mouth disease throughout the territory of the region and eradication of the hotbeds of the disease.

Further, government has appointed quarantine police on all roads leading to the external borders of the adverse site and 5 posts were set on roads leading from the threatened area. About 85,000 vehicles have been inspected and disinfected since the launch of prevention measures.

In this serious 63 veterinary specialists and 16 disinfection units from state budgetary institutions of veterinary administrations of cities and districts of the Krasnodar region were sent to the territory of the Mostovskoy district by the State Veterinary Department of the Krasnodar region to provide practical assistance in the eradication of outbreaks of foot-and-mouth disease. 22 state veterinary inspectors were sent for control and surveillance activities. The quarantine on the territory of Mostovskoy district of the Krasnodar Territory was canceled on August 4, 2013, after recovery of all sick animals and expiration of 21 days of observation.

Major efforts to prevent foot-and-mouth disease in amenable livestock were taken on the entire territory of the region:

- More than 638 thousands inspections of farmsteads of population engaged in livestock breeding were conducted;

- Clinical examination of more than 990 thousands cattle in farms of all forms of ownership was carried out;

- All cattle and small cattle were vaccinated against foot-andmouth disease twice (100\% coverage of livestock);

- 995 gatherings of citizens were held, where issues of footand-mouth disease prevention were discussed; 
- More than 115 thousands leaflets and memos "About the dangers of foot-and-mouth disease in animals and its prevention" were distributed;

- 114 meetings of special anti-epizootic commissions and crisis centers were held; and

- The State Veterinary Administration of the Krasnodar region, together with the Prosecutor's Office, carried out inspections of livestock facilities engaged in livestock breeding.

Strict adherence to the adopted comprehensive action plan for Prevention and Control of Foot-and-Mouth Disease in livestock by all stakeholders allowed stabilizing the hotbeds within the boundaries of their primary occurrence and eradicating the adverse site within the shortest possible time. All of the above indicates the need for continuous monitoring of the prevalence and level of postvaccinal foot-and-mouth antibodies in the buffer zone and for strict adherence to each item of the plan for measures against foot-and-mouth disease.

\section{Conclusion}

Timely detection of clinically sick animals and implementation of veterinary, sanitary and quarantine measures allowed to eradicate foot-and-mouth disease in the Krasnodar region in 2013 caused by the A2166/Krasnodar/2013 isolate of "Iran-2005" genetic line, "Asia" topotype, which was exotic for the Russian Federation and genetically similar to isolates A2167/Pregradnoe/KarachaevoCherkess/2013 and A2164/Gamruha/Karachaevo-Cherkess/2013 within the boundaries of its primary occurrence. Since 2013, the Krasnodar region was included in a safe zone, where prophylactic immunization of cattle and small cattle against foot-and-mouth disease is carried out. Due to this, stepped-up surveillance (both passive and targeted) is carried out in the Krasnodar region, in accordance with provisions of Articles 8.8.40. - 8.8.41 and Article 8.8.42 of the OIE Code, and, based on its results (for example, the signs of the circulation of the foot-and-mouth disease virus, including antibodies to nonstructural polyprotein of the foot-andmouth disease virus), zoosanitary measures are taken to prevent the spread of the foot-and-mouth disease virus to the rest of the country or to other areas. Taking into account the existing physical and geographical cordons, surveillance measures in the Krasnodar region are being held permanently. The obtained data indicated that different levels of the foot-and-mouth colostral antibodies were found in the sera of newborn calves. Antibodies to the foot-and-mouth disease virus of type A were found in $50 \%$ of samples, antibodies to the virus of type $\mathrm{O}$ and Asia-1 were found in $47 \%$ of sera. The foot-and-mouth antibodies were detected only in very low titers and in sera of individual newborn calves born 120-130 days after vaccination of cows against foot- and-mouth disease. The results of the epizootological examination of foot-and-mouth disease hotbeds and data of laboratory tests of newborn calves' sera for the presence of colostral antibodies indicate the need for a detailed study of this problem, development of recommendations for the creation of intense colostral foot-and-mouth immunity in the areas of high-risk of the virus penetration and revision of the scheme of young animals vaccination.

\section{Conflict of Interest}

Authors would hereby like to declare that there is no conflict of interests that could possibly arise.

\section{References}

Burdov AN, Dudnikov AI, Malyarets PV (1990) Foot-and-mouth disease (In Russian). Agropromizdat, Pp. 320.

Dzhailidi GA, Krivonos RA, Lysenko AA (2013) Epizootic specifics of foot-and-mouth disease in cattle (In Russian). Animal Heath in Kuban 5: 15-17.

Kharatyan S (2016) Invasion of a new strain of the foot-andmouth disease virus on the territory of Armenia (In Russian). Proceeding of the $7^{\text {th }}$ West Eurasia FND Roadmap Meeting, Kyrgystan, April 2016, Pp.108-117.

Knight-Jones TJ, Bulut AN, Gubbins S, Stärk KD, Pfeiffer DU, Sumption KJ, Paton DJ (2014) Retrospective evaluation foot-andmouth disease vaccine effectiveness in Turkey. Vaccine 32: 18481855. DOI: 10.1016/j.vaccine.2014.01.071.

Knight-Jones TJ, Bulut AN, Gubbins S, Stärk KD, Pfeiffer DU, Sumption KJ, Paton DJ (2015) Randomized field trial to evaluate serological response after foot-and-mouth disease vaccination in Turkey. Vaccine 33: 805-811.

Koshchaev AG, Shchukina IV, Semenenko MP, Sergeevna AK, Vasilevich KV (2016) Amino acid profile of meat of specialized beef breeds. Research Journal of Pharmaceutical, Biological and Chemical Sciences 7: 670-676.

Mikhalishin DV (2013) Duration of immunity in cattle vaccinated with foot-and-mouth oil-emulsion vaccine depending on its activity. Animal Health and Feeding 5: 29-30.

Mischenko AV (2015) Epizootic situation with foot-and-mouth disease in Western Eurasia 2015 (In Russian). $7^{\text {th }}$ Annual West Eurasia FND Roadmap Meeting, Kyrgystan, April 2016. - Pp. 423-435.

Mishchenko AV, Mishchenko VA (2015) About the ways of spreading and mechanisms of transmission of the foot-and-mouth 
disease virus (In Russian). Animal Health 8: 19-22.

Mishchenko AV, Mishchenko VA, Dudnikov SA (2011)

Experience of liquidation of FMD outbreaks in primary foci (In Russian) - Veterinariya. - Moscow 11: 7-12.

Mishchenko AV, Mishchenko VA, Dzhailidi GA, Krivonos RA, Yakubenko EV (2013) Field efficiency of vaccines against footand-mouth disease (In Russian). Veterinariya Kubani. Krasnodar 4 : 3-5.

Nersesyan SE, Sarkisyan RA, Gabrielyan MA (1997) Colostral immunity and active immunization of young cattle against FMD (In Russian). - Vladimir Pp. 63.

Onischuk PD, Semenenko MP, Kuzminova EV, Koshchaev AG (2016) Selective Mechanisms of Antiviral Effect of Triazole Derivatives in a Transplantable Virus-Producing Cell Culture of Hamadryas Baboon. Research Journal of Pharmaceutical, Biological and Chemical Sciences 7 : 1778-1782.

Paril PK, Sajjanar CM, Bayry J (2014) Neutralizing antibody responses to foot-and-mouth disease guadrivalent (type $\mathrm{O}, \mathrm{A}, \mathrm{C}$ and Asia 1) vaccines in growing calves with pre-existing maternal antibodies. Veterinary Microbiology 169: 233-235.

Plutakhin GA, Koshchaev AG, Donnik IM (2016) Quality assessment of chicken meat by analysis-of-variance method.
Research Journal of Pharmaceutical, Biological and Chemical Sciences 7: 2293-2299.

Radchenko VV, Ilnitskaya EV, Rodionova AS, Shuvaeva TM, Lysenko YA, Plutakhin GA, Manolov AI, Donnik IM, Koshchaev AG (2016) Identification of autochthonous strains as a basis for the development of the therapeutic and profylactic probiotics. Russian Journal of Biopharmaceuticals 8: 3-12.

Rakhmanov AM, Kremenchugskaya SR, Kamalova NE (2013) Evaluation of immune status in cattle after vaccination in FMD buffer zone (In Russian). - Vladimir Pp. 14-19.

Shcherbakov AV, Timina AM, Zinyakov NG (2014) Phylogenetic analysis of isolates of the foot-and-mouth disease virus that caused outbreaks in Russia in 2013 (In Russian). Animal Health 7: $22-25$.

Starostina NG, Koshchaev AG, Ratner EN, Tsiomenko AB (1997) Assessment of cell-surface hydrophobicity in methanotrophic bacteria by their adherence to hydrocarbons. Microbiology 66 : 151-156.

Upadhyaya S, Ayelet G, Paul G, King DP, Paton DJ, Mana Mahapatra M (2014) Genetic basis of antigenic variation in footand-mouth disease serotype A viruses from the Middle East. Vaccine 32: 631-638. doi: 10.1016/j.vaccine.2013.08.102. 